\title{
Embodying Relation
}




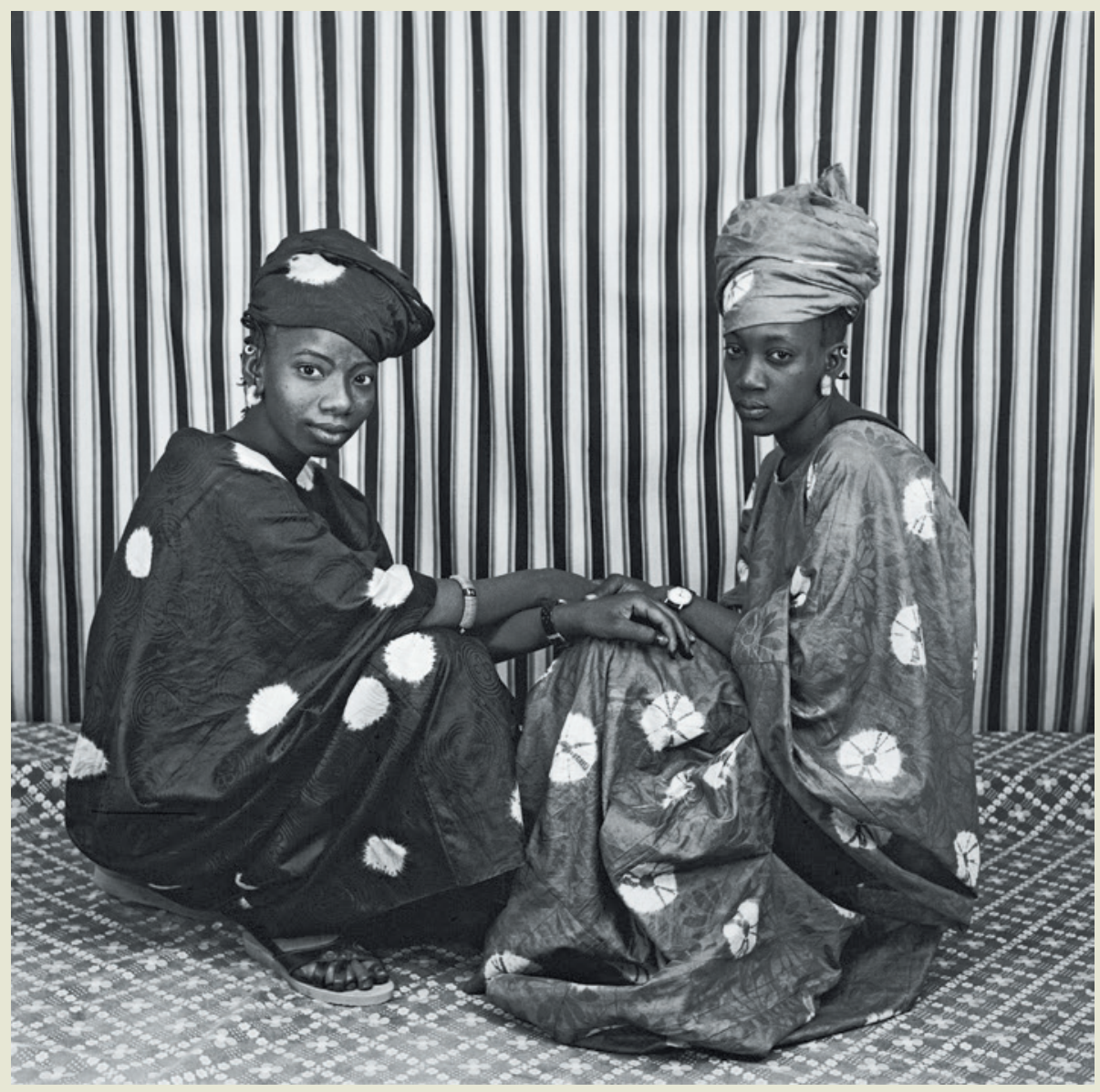




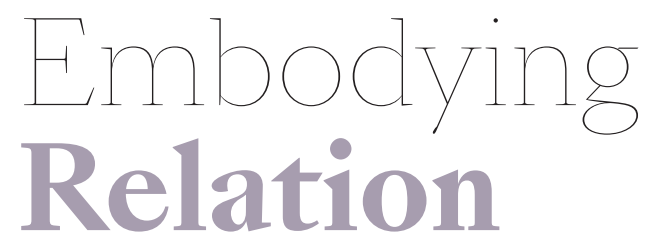

ART PHOTOGRAPHY IN MALI

\section{Allison Moore}

DUKE UNIVERSITY PRESS DURHAM AND LONDON 2020 
(C) 2020 Duke University Press

All rights reserved

Printed in the United States of America on acid-

free paper $\infty$. Typeset in Portrait by BW\&A Books.

Designed by Amy Ruth Buchanan.

Cover art: Fatoumata Diabaté, Sutigi, Bamako, 20I2. Courtesy of the artist and Patrice Loubon Gallery.

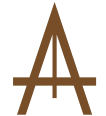

\section{ART HISTORY}

PUBLICATION INITIATIVE

This book is made possible by a collaborative grant from the Andrew W. Mellon Foundation.

Duke University Press gratefully acknowledges the University of South Florida Publications Council Grant and School of Art and Art History, which provided funds toward the publication of this book.

\section{Library of Congress}

Cataloging-in-Publication Data

Names: Moore, Allison (Art historian), author. Title: Embodying relation : art photography in Mali / Allison Moore.

Other titles: Art history publication initiative. Description: Durham :

Duke University Press, 2020. | Series: Art history publication initiative | Includes bibliographical references and index.

Identifiers: LCCN 20I9046724 (print)

LCCN 20I9046725 (ebook)

ISBN 978I47800597I (hardcover)

ISBN 978I478006626 (paperback)

ISBN 978I478007340 (ebook)

Subjects: LCSH: Glissant, Édouard, 1928-20IIPhilosophy. | Photography-Mali-2oth century. | Art, Malian-Mali-Bamako. | Postcolonialism and the arts-Mali. | Photography-Political aspectsMali. | Photography, Artistic.

Classification: LCC N7399.M3 M66 2020 (print) | LCC N7399.M3 (ebook) | DDC 770-dc23

LC record available at https://lccn.loc.gov/ 2019046724

LC ebook record available at https://lccn.loc.gov/ 2019046725 